\title{
JNPH
}

Volume 6 No. 2 (Oktober 2018)

(C) The Author(s) 2018

\section{GEL LIDAH BUAYA DALAM MENGURANGI PRURITUS}

\author{
ALOE VERA GEL IN REDUCING PRURITUS \\ FATIMAH KHOIRINI \\ POLTEKKES KEMENKES BENGKULU JURUSAN KEPERAWATAN \\ JALAN INDRA GIRI NO 3 PADANG HARAPAN BENGKULU \\ E-mail : fatimahkhoirini80@ymail.com
}

\begin{abstract}
ABSTRAK
Penatalaksanaan pasien Gagal Ginjal Kronik (GGK) yaitu pengobatan segera terhadap infeksi untuk mencegah infeksi sampai ke ginjal karena pasien mengalami penurunan imunitas. Pasien GGK hampir semua memiliki gangguan dermatologis, diantaranya pruritus. Penanganan farmakologis banyak menimbulkan efek samping. Salah satu bahan alami adalah lidah buaya. Lidah buaya sebagai pelembab, antibiotik dan mengatasi rasa gatal. Penelitian ini bertujuan untuk menganalisa efektifitas gel lidah buaya sebagai bahan alternatif tindakan keperawatan pada pruritus penderita GGK. Jenis penelitian ini adalah Eksperiment menggunakan pre test post test control group design, tehnik pengambilan sampel dengan random sampling. Jumlah responden 36 orang yaitu : 18 orang kelompok kontrol pemberian lotion kulit gel placebo 2 kali sehari setelah mandi selama 3 hari dan 18 orang kelompok eksperiment dengan pemberian gel lidah buaya 2 kali sehari setelah mandi selama 3 hari. Observasi menggunakan lembar observasi modifikasi Akhyani dan rumus pruritus Stahl-backdahl. Dianalisis dengan uji paired sample T-test. Hasil Uji statistik menunjukkan ada perbedaan bermakna pruritus sebelum dan sesudah pemberian gel lidah buaya dengan nilai pruritus $(\mathrm{p}=0.000)$. Implikasi dari penelitian ini adalah Gel lidah buaya bisa dipertimbangkan menjadi bahan alternatif tindakan keperawatan pada pruritus penderita GGK.
\end{abstract}

Kata kunci : Gel lidah buaya, Pruritus.

\begin{abstract}
The management of patients with Chronic Renal Failure (CRF) is the immediate treatment of the infection to prevent infection to the patient's kidney due to decreased immunity. CRF patients almost all have dermatological disorders, including pruritus. Pharmacological treatment causes a lot of side effects. One natural ingredient is aloe vera. Aloe vera as a moisturizer, antibiotics and as well itching. This study aims to analyze the effectiveness of aloe vera gel as a material alternative to nursing implementations in pruritus CRF patients in Semarang hospitals. This type of research is experiment with using pretest posttest control group design, selection sampling with random sampling taking random table. The number of respondents 36 people, that are 18 people giving the control group a placebo gel skin lotion 2 times daily after bath for 3 days and 18 people experimental group with the administration of aloe gel 2 times daily after bath for 3 days. Observations using Akhyani modifications observation sheet and formula Stahl-Backdahl pruritus. analyzed with paired sample T-test. Statistical test results
\end{abstract}


showed no significant difference pruritus before and after administration of aloe vera gel with the value of pruritus $(\mathrm{p}=0.000)$. The implication of this study is the Aloe vera gel can be considered to be alternatives to nursing implementations pruritus patients with CRF.

\section{Keywords : Aloe vera gel, Pruritus.}

\section{PENDAHULUAN}

Pasien dengan penyakit ginjal stadium lanjut hampir semua memiliki minimal satu gangguan dermatologis. ${ }^{1}$ Manifestasi kulit paling umum timbul pada penyakit ginjal stadium lanjut diantaranya pruritus. Hal ini juga predisposisi terhadap infeksi karena membahayakan pertahanan kulit normal. Tertundanya penyembuhan luka pada pasien penyakit ginjal stadium lanjut ini meningkatkan risiko infeksi. ${ }^{1}$ Salah satu penatalaksanaan pasien Gagal Ginjal Kronik (GGK) yaitu pengobatan segera terhadap infeksi untuk mencegah infeksi sampai keginjal karena pada penderita Gagal ginjal kronik (GGK) terjadi penurunan imunitas. ${ }^{2}$

Selama ini pengobatan pilihan untuk uremik pruritus yaitu emolien, topikal capsaicin cream, ultraviolet B fototerapi, gabapentin, arang aktif oral dan nalfurafine, antagonis opiat. ${ }^{5}$ Pengobatan ultraviolet B dikontraindikasikan penggunaan jangka lama. Pengobatan dengan gabapentin jika diberikan dalam waktu lama dapat terakumulasi dan menyebabkan neurotoksik. ${ }^{6}$ Penggunaan Talidomid juga harus dibatasi penggunaannya karena berpengaruh pada kardiovaskuler dan neuropati periper sedangkan penggunaan tacrolimus jangka panjang belum diketahui dan tidak direkomendasikan sampai mendapat data yang mendukung. ${ }^{7}$

Alangkah baiknya jika kita mencoba salah satu bahan alami yaitu lidah buaya yang dipercaya dapat mengatasi keluhan pada kulit tersebut.

Banyak penelitian menyebutkan daun lidah buaya dapat sebagai anti inflamasi, anti jamur, anti bakteri dan regenerasi sel. ${ }^{8}$ Telah diteliti oleh Atik tanaman lidah buaya dapat digunakan untuk perawatan luka, penelitian oleh Wijaya lidah buaya dapat digunakan untuk luka bakar, penelitian oleh Tjahayani lidah buaya dapat digunakan pada luka rongga mulut ${ }^{9}$. Serta penelitian Rajin didapatkan bahwa pemberian kompres lidah buaya dapat menurunkan tingkat phlebitis pada 8 jam ketiga setelah pemberian kompres. ${ }^{10}$ Penelitian eksperimental laboratoris di laboratorium Fitokimia Fakultas Farmasi Unair oleh Hidayah menyimpulkan penggunaan gel aloe vera tidak toksik terhadap sel fibroblast sehingga aman untuk digunakan dalam rongga mulut. ${ }^{11}$

Menurut Rajeswari lidah buaya dapat digunakan untuk pengobatan luar untuk beberapa kondisi kulit seperti ekszema, luka dan luka bakar. Lidah buaya juga bisa digunakan sebagai pengurang nyeri dan peradangan. Lidah buaya juga dapat digunakan sebagai antiseptik dan antibiotik. ${ }^{12}$ Lidah buaya ini menghasilkan 6 agent antiseptik seperti lupeol, salicylic acid, urea nitrogen, cinnamonic acid, phenol dan sulphur. Semua subtansi ini tergolong antiseptik karena dapat membunuh kuman atau mengontrol pembentukan bakteri jamur dan virus. ${ }^{12}$ Lidah buaya menghambat migrasi sel PMN (neutrophil) ke jaringan vena yang meradang, sehingga proses inflamasi vena dihambat. Kandungan asam amino, glikoprotein dan aloe emodin dalam lidah buaya mempercepat perkembangan selsel baru dalam proses regenerasi epitel pembuluh darah. ${ }^{10}$

Gel lidah buaya dapat melembabkab kulit karena mengandung air yang banyak. ${ }^{13}$ Gel lidah buaya mempunyai kadar air tinggi yaitu 94,83 \%. ${ }^{14}$ penelitian oleh Schulz mengatakan gel lidah buaya mengandung air 99\% dan yang lainnya glucomanans, asam amino, lipid, sterol dan vitamin. ${ }^{15}$ Mucopolysakarida membantu dalam mengikat kelembaban kulit. Lidah buaya 
menstimulasi fibroblast yang menghasilkan kolagen dan serat elastis yang membuat kulit lebih elastis dan mengurangi kerutan. Asam amino di dalam lidah buaya juga mengurangi kulit yang kasar dan zink bertindak sebagai astringent untuk mempererat pori-pori kulit juga mempunyai efek anti jerawat. ${ }^{13}$

Lidah buaya mengandung zat aktif lignin yang mempunyai kemampuan penyerapan tinggi sehingga memudahkan peresapan gel ke dalam kulit atau mukosa. ${ }^{8}$ Menurut Kumar biasanya lidah buaya digunakan sebagai pelembab, penelitian menunjukkan lidah buaya efektif mengurangi kekeringan pada kulit, membersihkan jerawat, alergi pada kulit, noda kehitaman dan kulit yang berwarna tidak rata dan membuat kulit menjadi cerah ${ }^{16}$

Sabun yang mengandung lidah buaya juga telah diteliti oleh Olsen dapat menurunkan insiden reaksi kulit pada pasien dengan kemoterapi. ${ }^{17}$ Lidah buaya juga mengandung glikoprotein dengan sifat anti alergi, yang disebut alprogen. ${ }^{18}$ Alprogen menghalangi arus masuk kalsium ke sel mast, dengan demikian menghambat antigen antibody dalam pelepasan histamine dan leukotriene dari sel mast. ${ }^{19}$

Pada penelitian tentang uji racun dan fungsi hati terhadap penggunaan lidah buaya oleh Sultana di dapatkan hal sebagai berikut : tidak terdapat kejadian kematian hewan uji selama total periode eksperiment, terdapat peningkatan bilirubin total yang signifikan pada hewan uji coba yang mendapat aloe vera, terdapat penurunan Bilirubin direct, SGPT, $\gamma$ GT, alkalin phospat dan SGOT yang signifikan selama 30 hari pemberian aloe vera. $^{20}$ Lidah buaya mempunyai efek hepatoprotektif. ${ }^{2}$ Menurut Ramachandraiagari perbandingan hasil histologi ginjal mencit diabetes yang diberi ekstrak lidah buaya terdapat perbaikan epitel pada tubulus sedangkan pada yang tidak diberi lidah buaya terdapat kerusakan glomerulus yang komplit serta pembesaran tubulus. Aktifitas Superoxide dismutase (SOD), Catalase (CAT), Glutathione peroxidase (GPx) dan
Glutathione reductase (GR) meningkat di dalam jaringan hati dan ginjal mencit diabetes pada pemberian ekstrak lidah buaya. ${ }^{22}$

Pada penelitian pemeriksaan histologi jaringan ginjal mencit yang mengalami diabetes oleh Bolkent terdapat regenerasi jaringan epitel tubulus ginjal yang signifikan setelah pemberian glibenclamid dan ekstrak lidah buaya. Walaupun pada masing-masing individu berbeda, tikus yang diberi gel lidah buaya regenerasinya lebih baik sehingga jaringan ginjal yang rusak akibat diabetes lebih sedikit dibanding yang hanya mendapatkan glibenclamid saja dengan penurunan derajat kerusakan jaringan ginjal berubah dari kerusakan sedang menjadi kerusakan derajat rendah. Juga ditemukan ekstra lidah buaya dapat mengurangi level urea dan kreatinin. ${ }^{23}$

Hasil penelitian Chatterjee mengungkapkan gel ekstrak lidah buaya mempunyai efek perlindungan yang sangat signifikan terhadap cisplatin dan gentamicin yang berakibat neprotoxic, ini mengindikasikan bahwa ekstrak lidah buaya mempunyai efek nefroprotektif yang signifikan. ${ }^{24}$

Bagaimana jika lidah buaya ini juga digunakan untuk mengatasi pruritus pada kulit pasien Gagal Ginjal Kronik (GGK) yang sering mengeluh gatal di seluruh tubuh dengan anti alergi yang dikandungnya.

\section{METODE PENELITIAN}

Dalam penelitian ini menggunakan desain eksperimen dengan menggunakan pre test post test control group design.

Penelitian ini ada dua kelompok yaitu satu kelompok perlakuan dengan gel lidah buaya dan satu kelompok kontrol dengan placebo Carboxyl Methyl Cellulosa (CMC).

Populasi dari penelitian ini adalah seluruh pasien Gagal Ginjal Kronik yang menjalani terapi Hemodialisa di Rumah Sakit Umum Daerah Kota Semarang pada bulan oktober tahun 2015 berjumlah 75 orang.

Jumlah minimal sampel pada penelitian ini adalah 15 subyek per group ditambah kemungkinan drop out $20 \%$ sehingga 
menjadi 18 orang per group. Sampel yang diambil adalah yang memenuhi persyaratan penelitian sebagai berikut:

1. Kriteria inklusi

a. Pasien GGK yang berobat pada saat penelitian bulan Oktober 2015.

b. Pasien yang mengalami pruritus.

c. Tidak masuk dalam kriteria penurunan kesadaran.

d. Pasien kooperatif dan saat penelitian pasien berada di semarang.

e. Bersedia menjadi responden dan mengikuti tata cara penelitian.

2. Kriteria eksklusi

a. Menggunakan gel atau obat-obatan yang bertujuan mencegah atau mengatasi pruritus

b. Memiliki alergi sediaan atau hasil pemeriksaan patch test positif.

Pada penelitian ini cara merandom subyek dengan menggunakan tabel angka random.

Intrumen yang digunakan adalah lembar observasi tentang pruritus pada kulit pasien GGK berdasarkan modifikasi Akhyani dan penghitungan pruritus berdasarkan rumus pruritus Stahl-Bachdahl.

\section{Proses penelitian}

Setelah didapat kelompok kasus dan kelompok kontrol, peneliti menjelaskan ulang prosedur penelitian kepada responden yaitu pengolesan gel pada daerah xerosis dan pruritus 2 kali sehari setelah mandi selama 3 hari dan akan ada enumerator yang akan datang kerumah saat pagi dan sore selama 3 hari untuk membantu pengolesan gel.

Untuk kelompok kontrol peneliti menerapkan sistim pemberian placebo dengan tunda yaitu setelah pemberian gel placebo diberikan juga gel lidah buaya.

Untuk mengetahui alergi atau tidak terhadap sediaan gel lidah buaya dilakukan uji pacth tes atau uji tempel yang dilakukan pada lengan atas bagian lateral atau lengan bawah bagian volar, setelah 4 jam uji tempel, dilakukan pembacaan hasil jika tidak ada efek gatal dan merah bisa di terapkan pada daerah pruritus.

Responden yang telah dilakukan tes alergi kemudian dilakukan penilaian pre eksperiment dengan mengobservasi derajat pruritus pada hari ke-0. Keesokan harinya mulai dilakukan eksperimen dengan pengolesan gel lidah buaya pada responden kelompok kasus dan pengolesan gel placebo pada responden kelompok kontrol selama 3 hari. Setelah 3 hari pemakaian gel dilakukan observasi tentang perubahan keluhan kulit yang mengalami pruritus. Begitu seterusnya sampai semua responden telah dilakukan eksperiment.

\section{Pengolahan dan analisa data}

Data dari lembar observasi diolah sebagai berikut :

a. Lokasi /distribusi

Mendapat nilai nol jika tidak ada pruritus, nilai satu jika timbul pruritus $100 \%$ pada salah satu daerah dari 8 area pruritus dan seterusnya sehingga nilai maksimal adalah 8 .

b. Intensitas / keparahan pruritus

Mendapat skor 1 jika timbul kadang-kadang dan skor 2 jika timbul terus-menerus. Periodic/kadang-kadang adalah keluhan gatal tidak terus menerus hanya beberapa waktu dan mempunyai jeda. Continuous/terus-menerus adalah keluhan gatal timbul sepanjang hari dan sepanjang malam.

c. Gangguan tidur : skor 1 jika ada gangguan dan skor 0 tanpa gangguan tidur

Kemudian untuk mengetahui skore pruritus gunakan rumus dibawah ini :

pruritus $=($ keparahan $\mathrm{x}$ distribusi $)+$ gangguan tidur

Nilai maksimal pruritus adalah 17.

Data dianalisa menggunakan uji paired sample T-test. 


\section{HASIL PENELITIAN}

Berdasarkan penyebab penyakit Gagal Ginjal Kronik pada penelitian ini responden terbagi dalam dua kelompok yaitu Gagal Ginjal Kronik karena komplikasi dari Hipertensi (HT) dan Gagal Ginjal Kronik karena komplikasi dari penyakit Diabetes Melitus (DM) Untuk lebih rinci tentang penyakit penyebab GGK dapat dilihat pada diagram berikut :

\section{Diagram 1. Deskripsi responden} penderita Gagal Ginjal Kronik di RSUD Kota Semarang berdasarkan penyakit penyebab GGK tahun $2015(n=36)$

\section{penyakit penyebab GGK}

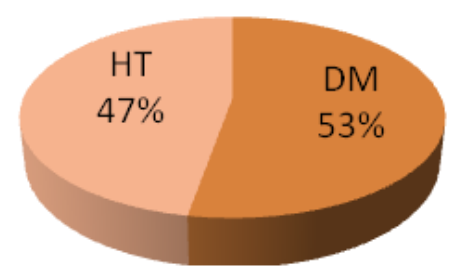

Dari diagram diatas dapat dilihat yang terbanyak menjadi penyakit penyebab Gagal Ginjal Kronik adalah penyakit Diabetes Melitus (53\%)

Pasien GGK di RSUD Kota Semarang tahun 2015 rutin melaksanakan HD dengan frekuensi dua kali seminggu. Berdasarkan frekuensi Haemodialisa yang sudah dijalani responden terbagi menjadi dua kelompok yaitu kelompok yang frekuensinya kurang dari 100 kali dan lebih dari 100 kali. Untuk lebih rinci tentang penyakit penyebab GGK dapat dilihat pada diagram berikut :

Diagram 2. Deskripsi responden penderita Gagal Ginjal Kronik di RSUD Kota Semarang berdasarkan frekuensi HD pasien GGK $(n=36)$

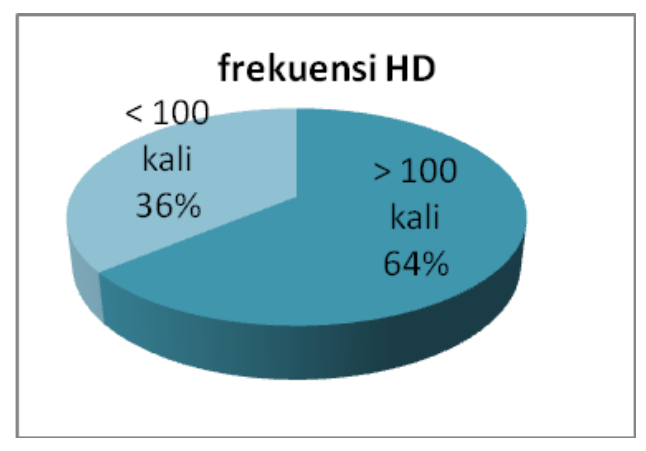

Dari diagram diatas dapat dilihat yang responden terbanyak telah melakukan haemodialisa lebih dari 100 kali (64\%).

Uji homogenitas (uji kesetaraan) dilakukan untuk variabel yang diduga akan mempengaruhi masing-masing kelompok intervensi yang penyakit penyebab dan frekuensi HD, maka dilakukan uji homogenitas sebelum dilakukan intervensi pemberian gel lidah buaya dan placebo. Uji homogenitas dilakukan dengan menggunakan uji independent $t$ test dan chi squar test. Hasil uji kesetaraan menunjukkan bahwa tidak ada perbedaan yang signifikan antara frekuensi hemodialisa dan penyakit penyebab GGK responden sebelum dilakukan intervensi antara kelompok (setara) dengan nilai $p$ value $>0,05$ pada $\alpha=0,05$. Gambaran karakteristik dan kesetaraan responden pada masingmasing kelompok intervensi dijelaskan pada tabel berikut :

Tabel 1. Gambaran karakteristik responden dan kesetaraan sebelum dilakukan intervensi pada kelompok kontrol dan kelompok eksperiment di RSUD Kota Semarang tahun $2015(n=36)$

\begin{tabular}{ccccc}
\hline No & Variabel & $\begin{array}{c}\text { Klp } \\
\text { eksperiment } \\
(\mathrm{n}=18)\end{array}$ & $\begin{array}{c}\text { Klp } \\
\text { kontrol } \\
(\mathrm{n}=18)\end{array}$ & P value \\
\hline 1 & Frekuensi HD & 1.5 & 1.7 & $0,87^{*}$ \\
& ,mean (SD) & $(0.5)$ & $(0.4)$ & \\
\hline 2 & Penyakit & & & \\
& penyebab & $10(52.6)$ & $9(47.4)$ & $1,0^{* *}$ \\
& $\sum(\%)$ & $8(47.1)$ & $9(52.9)$ & \\
& DM & & & \\
\hline & & &
\end{tabular}


$\mathrm{SD}$, standar deviasi

*nilai p diperoleh melalui uji $\mathrm{t}$

**nilai p diperoleh melalui cross tabs

\section{Pengaruh karakteristik responden terhadap penurunan keluhan pruritus}

Untuk mengetahui apakah karakteristik responden mempengaruhi hasil penelitian maka dilakukan uji corelations dan uji $t$ independent. Berdasarkan hasil uji corelations antara pruritus dengan karakteristik responden dimaksud dapat dilihat dari tabel berikut :

Tabel 2. Hubungan pruritus dengan karakteristik pasien GGK di RSUD Kota Semarang tahun $2015(n=36)$

\begin{tabular}{ccc}
\hline No & $\begin{array}{c}\text { Variabel } \\
\text { mean (SD) }\end{array}$ & $\begin{array}{c}\text { pruritus } \\
\text { mean (SD) } \\
\text { p value }\end{array}$ \\
\hline 1 & Frekuensi HD & \\
& $1.6(0.4)$ & $4.3(3.9)$ \\
& & $0.670^{*}$ \\
\hline 2 & Penyebab & \\
& DM & $5.13(4.40)$ \\
& HT & $3.37(3.37)$ \\
& & $0.192^{* *}$ \\
\hline
\end{tabular}

SD, standar deviasi

*nilai p diperoleh melalui uji korelasi

**nilai $\mathrm{p}$ diperoleh melalui uji $\mathrm{t}$

Nilai hubungan antara pruritus setelah pengolesan gel dengan frekuensi hemodialisa dan penyakit penyebab GGK responden didapat nilai $p$ value $>0,05$ sehingga dapat disimpulkan tidak ada hubungan antara nilai pruritus dengan karakteristik responden.

\section{Gambaran pruritus sebelum intervensi}

Keluhan pruritus dinilai sebelum pemberian gel. Hasil penilaian pruritus sebelum intervensi pada kelompok eksperiment didapatkan rata-rata 6,3 dan kelompok kontrol didapatkan pruritus ratarata adalah 3,8. Hasil statistik menunjukkan bahwa skor xerosis pada masing-masing kelompok sebelum dilakukan pengolesan gel adalah setara ( $p$ value $0.104>\alpha=0.05$ ), yang dapat dilihat pada table berikut :

Tabel. 3. Gambaran kesetaraan pruritus sebelum dilakukan intervensi di RSUD Kota Semarang $2015(n=36)$

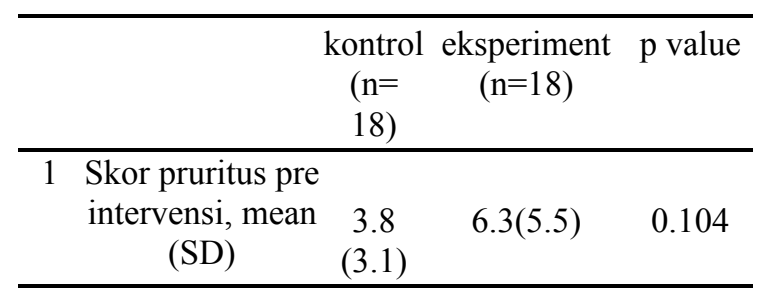

SD,standar deviasi

Nilai $p$ diperoleh melalui uji $t$ independent

Pengaruh pemberian gel lidah buaya dan gel placebo terhadap pruritus pasien Gagal Ginjal Kronik

Untuk mengetahui hasil perbedaan pruritus maka digunakan uji $t$ dependen dengan membandingkan antara nilai pruritus pre dengan nilai pruritus post pada masingmasing kelompok.

1. Pengaruh gel placebo terhadap pruritus kelompok kontrol

Pada pruritus nilai mean sebelum intervensi 3.8 dan setelah intervensi 3.7. Setelah di uji dengan uji $t$ dependen didapatkan hasil nilai pruritus ( $\mathrm{p}$ value 0.236 $>\alpha=0.05$ ). Berdasarkan statistik ini diketahui nilai $\mathrm{p}>\alpha=0.05$ sehingga dapat disimpulkan tidak ada perbedaan yang signifikan nilai pruritus sebelum dan sesudah pemberian gel placebo pada kelompok kontrol.

2. Pengaruh gel lidah buaya terhadap pruritus kelompok eksperiment

Pada kelompok eksperiment didapatkan nilai mean pruritus sebelum intervensi 6.3 dan nilai mean pruritus setelah intervensi 4.8 setelah di uji dengan uji $t$ dependen didapat hasil nilai pruritus ( $\mathrm{p}$ value $0.000<\alpha=0.05)$. Sehingga dapat disimpulkan ada perbedaan yang signifikan nilai pruritus sebelum dan sesudah pemberian gel lidah buaya selama 3 hari 
pada kelompok eksperiment. Untuk lebih jelasnya dapat dilihat pada grafik berikut :

Grafik 1. Gambar perubahan nilai pruritus sebelum dan setelah di berikan intervensi gel lidah buaya dan gel placebo pada pasien GGK di RSUD Kota Semarang tahun 2015

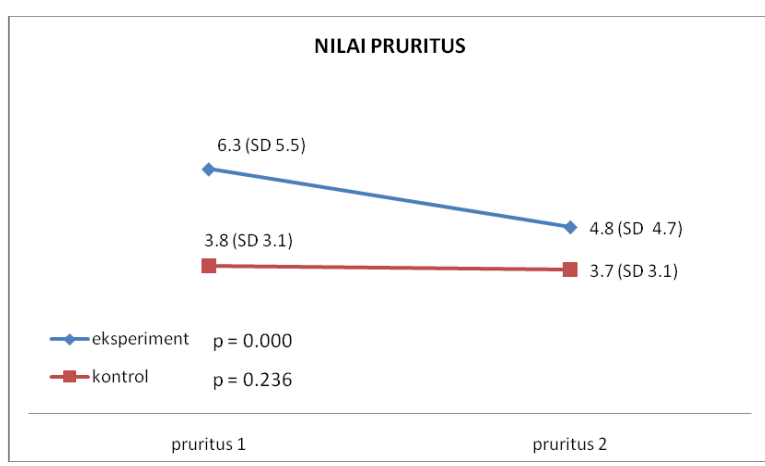

SD,standar deviasi

*Statistik signifikan (nilai p) diperoleh melalui uji $\mathrm{t}$

\section{PEMBAHASAN}

Gel lidah buaya dapat menurunkan keluhan pruritus karena gel lidah buaya dapat melembabkan kulit karena kandungan air yang tinggi dalam lidah buaya berdasarkan penelitian Ramadhia tahun 2012 kandungan air dalam lidah buaya yaitu 94,83 \%. ${ }^{14}$ Kandungan air dapat membuat kulit menjadi lembab hal ini sesuai dengan penelitian Okada tahun 2004 yang berjudul effect of skin care with an emollient containing a high water content on mild uremic pruritus. Emollient adalah sejenis pelembab berbahan dasar lipid dari tumbuhan dan hewan atau minyak mineral atau sintetik yang kandungan airnya $80 \%$. Pada penelitian Okada ini didapatkan penurunan pruritus yang signifikan disertai penurunan kekeringan kulit pada kelompok yang menggunakan emollient. ${ }^{25}$

Pada keadaan normal, air mengalir secara difusi dari dermis menuju ke epidermis melalui dua cara yaitu melalui stratum corneum dan ruang interseluler. Oleh sebab itu normal air akan keluar dari tubuh melalui epidermis, keadaan tersebut dikenal dengan istilah transepidermal water loss (TEWL). Proses difusi pasif terjadi karena terdapatnya perbedaan kandungan air dari stratum basalis $(60-70 \%)$, stratum granulosum (40-60\%) dan stratum corneum kurang dari $15 \%$ sehingga air mengalir dari stratum basalis ke stratum corneum. Dengan demikian maka stratum corneum merupakan barier hidrasi yang sangat penting dalam memepertahankan kelembaban kulit. Pada kulit yang sakit (terdapat kelainan epidermis), barier kulit melemah sehingga kecepatan TEWL meningkat 10 kali lebih besar dari normal. Dengan tingginya kandungan air dalam lidah buaya membantu mensuplai kebutuhan air pada kulit yang mengalami penurunan fungsi. ${ }^{26}$

Lidah buaya mengandung zat aktif lignin yang mempunyai kemampuan penyerapan tinggi sehingga memudahkan peresapan gel ke dalam kulit atau mukosa. ${ }^{19}$ Mucopolysakarida membantu dalam mengikat kelembaban kulit sehingga air tertahan didalam lapisan kulit, serta menstimulasi fibroblast yang menghasilkan kolagen dan serat elastis yang membuat kulit lebih elastis dan mengurangi kerutan. Kandungan lidah buaya yang lainnya adalah Asam amino yang berfungsi mengurangi kulit yang kasar serta zink bertindak sebagai astringent untuk mempererat pori-pori kulit. ${ }^{13}$

Lidah buaya bukan hanya dapat mengurangi kekeringan pada kulit pasien GGK tapi Sabun yang mengandung lidah buaya juga telah diteliti oleh Olsen dapat menurunkan insiden reaksi kulit pada pasien dengan kemoterapi. ${ }^{17}$ Penelitian invitro Tanaka tahun 2015 tentang pemberian $40 \mu \mathrm{g}$ aloe sterol secara oral setiap hari selama 2 minggu menunjukkan menurunnya kerutan kulit wajah pada wanita jepang yang berumur $\geq 40$ tahun karena aloe vera merangsang colagen dan hyaluronic acid yang diproduksi oleh dermal fibroblast. ${ }^{27}$

\section{Pengaruh gel lidah buaya terhadap pruritus}


Pada kelompok eksperiment nilai mean pruritus sebelum intervensi 6.3 dan nilai mean pruritus setelah intervensi 4.8 setelah di uji dengan uji $\mathrm{t}$ dependen didapat hasil nilai pruritus ( $\mathrm{p}$ value $0.000<\alpha=0.05$ ). Sehingga dapat disimpulkan ada perbedaan yang signifikan nilai pruritus sebelum dan sesudah pemberian gel lidah buaya selama 3 hari.

Menurut Rajeswari sifat lidah buaya menenangkan dan menyejukkan kulit yang meradang, nyeri kebas karena inflamasi dan mencegah timbulnya rasa gatal. ${ }^{12}$ Gel lidah buaya dapat menurunkan keluhan pruritus diduga karena lidah buaya mengandung glikoprotein dengan sifat anti alergi, yang disebut alprogen. ${ }^{18}$ Menurut Ro Alprogen menghalangi arus masuk kalsium ke sel mast, dengan demikian menghambat antigen antibodi dalam pelepasan histamin dan leukotriene dari sel mast. ${ }^{19}$

Alprogen juga muncul untuk menghambat beberapa sinyal serta masuknya ion kalsium blok, dan protein kinase $\mathrm{C}$ dan fosfolipase $\mathrm{D}$ serta menghambat pembentukan 1,2 diasilgliserol massa dan fosfolipase kegiatan selama aktivasi sel mast. ${ }^{19}$ Penelitian Keithi- Reddy menyatakan pruritus disebabkan lepasnya histamin dari sel mast hal ini didukung oleh penelitian tentang fototerapi ultraviolet-B yang dapat menurunkan jumlah sel mast dan memperbaiki pruritus secara bermakna. ${ }^{28}$

\section{KESIMPULAN}

Terdapat perbedaan pruritus yang signifikan sebelum dan sesudah pemberian gel lidah buaya pada kulit pasien Gagal Ginjal Kronik. Implikasi dari penelitian ini adalah Gel lidah buaya bisa dipertimbangkan menjadi bahan alternatif tindakan keperawatan pada pruritus penderita GGK.

\section{SARAN}

Untuk peneliti selanjutnya dapat melaksanakan penelitian tentang perbedaan jumlah alprogen yang ada di lidah buaya untuk mengatasi xerosis atau jumlah alprogen minimal yang dapat digunakan untuk mengurangi xerosis pada pasien Gagal Ginjal.

\section{DAFTAR PUSTAKA}

1. Lynde C and John K. Skin manifestations of kidney disease conditions range from benign to life-threatening. 2007;15(2).

2. Stahle-Backdahl. Pruritus clinical aspect. The cause of uremic pruritus is unknow. Dermatol. 1995;14; dalam Harlim A. Pruritus Uremik pada penyakit GGK. Majalah kedokteran FK UKI. 2012: 28 (2).

3. Draelos Z.D. Dermatologic aspects of cosmetic : Therapeutic moisturizers. Dermatol Clin. 2000; 18(4) dalam Pray W.S.and Pray J.J. Managing Dry Skin. US Pharmacist. 2006:5:30(3).

4. Baumann L. Cosmetic dermatology: principles and practice. The McGrawhill. Companies. New York. 2002:1-8; dalam Pray W.S.and Pray J.J. Managing Dry Skin. US Pharmacist. 2006:5:30(3).

5. Kuypers DRJ. Skin problem in cronic kidney disease. Medscap.2009;5:158159.

6. Gunal AI, Goksel O, Tahir KY,Servin YG, Ercan K, Huseyin C. Gabapentin therapy for pruritus in haemodialysis patient: Randomized, placebo-controled, doubell-blind trial, Nephrol Dialysis Tranplant. 2004;19. Dalam Roswati E. Pruritus pada pasien hemodialisa. CKD203. 2013:40(4).

7. Mettang T, Weisshaar E. Pruritus : Control of itch in patient undergoing dialysis. 2010. 15(2)

8. Furnawanthi. Khasiat dan manfaat lidah buaya.cetakan 1. Jakarta. Argo Media Pustaka. 2002.

9. Tjahayani A, Aloe vera leaf anti inflamation's activity speeds pruritus the healing process of oral mucosa ulceration. (Thesis).

10. Rajin $M$, Indah $M$, Pemamfaatan kompres ekstra lidah buaya pada pasien 
phlebitis untuk mengurangi biaya di rumah sakit. (Thesis). 2008.

11. Hidayah B. Uji toksisitas aloe vera berbagai kosentrasi terhadap sel fibroblast. Fakultas kedokteran gigi Unair. 2006.

12. Rajeswari R, Umadevi M, Sharmila RC, Pushpa R, Selvavenkhades S, Sampath Kumar KP, Debjid B.aloe vera the miracle plant its medicinal and traditional uses in india. 2012;4:118-120

13. West DP, Zhu Y.evaluation of aloe vera gel gloves in the treatment of dry skin associated with occpruritusational exposure. Am J Infect Control.2003;31(1).

14. Ramadhia M. pembuatan tepung lidah buaya dengan metode foam - mat drying. (Thesis).2012.

15. Schulz V, Hansel R, Tyler VE. Rational phytoterapy: a physician guide to herbal medicine.Berlin:springer.1997. dalam Senan P. Aloe vera : a miracle plant with biological actions. World Journal of Pharmacy and Pharmaceutical science. 2014: 3(11).

16. Kumar K.P.S, Debjit B, Chiranjib, Biswijit. Aloe vera a potential herb and its medicinal importance. J.Chem.Pharm. Res. 2010;1;26

17. Olsen SL, Raub W Jr, Brandley C, Johnson M, Macias JL, Love V, Markoe A. The effect of aloe vera gel/mild soap versus mild soap alone in preventing skin reactions in patients undergoing radiation therapy.Oncol Nurs Forum. 2001;28(3).

18. Ro J.Y, Lee B.C, Kim J.Y, Chung Y.J, Chung M.H, Lee S.K, Jo T.H, Kim K.H, Park Y.I. Inhibitory mechanism of aloe single component (Alprogen) on mediator release in guinea pig lung mast cells activated with specific antigenantibody reactions. Journal of pharmacology and experimental therapeutic. 2000;1;119.

19. Hart LA, Nibbering PH, Van Den Bars ellar MT, Van Dijik H, Labadei RP. Effects of molecular constituents from aloe vera gel on oxidative metabolism and cytotoxic and bactericidal activities of human neutrophils. Int Journal Immunopharmacol. 1990:12.

20. Sultana N, Rahila N. gross toxicities and hepatoprotektif effect of aloe vera (L) burm.f.International Research J. Of Pharmacy.2012;10;106-107

21. Saleh I, Alqasaumi, Tawfiq A, Al Howiriny and Majed S, Abdel Hirsute. Curcumis prophatarum and bee propolis against experimentally induced liver injury in rats. Int J. Pharmacol.2008;4;213

22. Ramachandraiahgari RMY, Somesula SR, Adi PJ, Mannur IS, Enamala M, Matcha B. Protective role of ethanolic ekstrak of aloe vera antioxidant properties on liver and kidney of stertozotocin induced diabetic rat. Digest journal of nanomaterials and biostructures. 2012;7;175,180-181.

23. Bolkent S, Akev N, Ozsoy N, Inceli MS, Can A, Okyar A, Yanardag R. Effect of aloe vera leaf gel and pulp ekstracs on kidney in tipe-II diabetic rat. Indian Journal of experimental biology. 2004:42;49.

24. Chatterjee P, Muherjee A, Nandy S. Protective effects of the aqueous leaf extract of aloe barbadensis on gentamicin and cisplatin induced nefrotoxic rats. Asian Pacific journal of tropical Biomedicine. 2012;1756-1758.

25. Okada K, Matsumoto K. Effect of skin care with an emollient containing a high water content on mild uremic pruritus. Ther apherdial. 2004 oct 8 (5): 419

26. Purwandhani E, Effendi EHF. Pelembab dan emolien untuk kelainan kulit pada bayi dan anak. MDVI vol 27 no 4 september 2000 dalam Donna partogi : kulit kering 2008

27. Tanaka M, Misawa E, Yamauchi K, Abe $\mathrm{F}$, Ishizaki C, Effects of plant sterolderived from aloe vera gel on human dermal fibroblast in vitro and on skin condition in japanese women. Clint cosmet investig dermatol. 2015 feb 20: 8; 95-104 doi 10. 2147/CCID. S75441. 
28. Lungon JR.Uremik pruritus: a review. Hemodial int 2005;9. dalam Pardede S.O. Pruritus Uremic. Sari pediatric.2010:11(5). 